\title{
GASTRIC RESIDUAL VOLUME BY MAGNETIC RESSONANCE AFTER INTAKE OF MALTODEXTRIN AND GLUTAMINE: a randomized double-blind, crossover study
}

\author{
Luigi R BRIANEZ', Cervantes CAPOROSSI'1, Yure W de MOURA², Lorena A DIAS², \\ Regis V LEAL ${ }^{1}$ and José E de AGUILAR-NASCIMENTO'
}

\begin{abstract}
Context - The addition of glutamine in preoperative drinks may enhance the benefits of carbohydrate alone. Objective To evaluate the gastric residual volume after the intake of a beverage containing carbohydrate plus glutamine. Methods - Eleven healthy volunteers (24-30 years-old) were randomized in a crossover fashion to intake $400 \mathrm{~mL}$ ( $4 \mathrm{~h}$ before) and $200 \mathrm{~mL}$ ( $2 \mathrm{~h}$ before) of a beverage containing either 12.5\% maltodextrin (carbohydrate group) or $12.5 \%$ maltodextrin plus $15 \mathrm{~g}$ of glutamine (glutamine group) in two different moments 7 days apart. Magnetic ressonance was performed to measure the gastric residual volume $(\mathrm{mL}) 120$ and 180 minutes after the last ingestion. Results - Gastric residual volume similar to basal condition was found after $2 \mathrm{~h}$ and $3 \mathrm{~h}$ of the intake of beverages. There was no difference in the mean \pm SD GRV $(\mathrm{mL})$ found at 120 minutes (carbohydrate group: $22.9 \pm 16.6$ and glutamine group: $19.7 \pm 10.7$ ) and at 180 minutes (carbohydrate group: $21.5 \pm 24.1$ and glutamine group: 15.1 \pm 10.1 ) between the two drinks. Conclusion - Gastric emptying is efficient, and occurs in up to two hours after the intake of a beverage containing either carbohydrate alone or carbohydrate associated with glutamine. The addition of glutamine to carbohydrate-enriched drink seems to be safe for the use up to $2 \mathrm{~h}$ before an operation.
\end{abstract}

HEADINGS - Gastric emptying. Preoperative care. Carbohydrates. Glutamine. Magnetic resonance imaging.

\section{INTRODUCTION}

Preoperative carbohydrate $(\mathrm{CHO})$ treatment $2 \mathrm{~h}$ before the induction of anesthesia over traditional preoperative fasting of 6-8 hours is one of modern prescription recommended by evidence-based multimodal protocols to enhance postoperative recovery ${ }^{(1,5,11,15,26)}$. The practice of overnight fasting, also known as "nil per oral" (NPO) after midnight was based on a retrospective study in non-elective surgery patients carried out by Mendelson in $1946^{(21)}$. The rationale for this is the minimization of the risks of bronchial aspiration of gastric contents during anesthesia ${ }^{(19)}$.

However, prolonged preoperative fasting increases insulin resistance and the organic response to trauma ${ }^{(2,23)}$. In addition, perioperative symptoms such as nausea, vomiting, hunger, thirst and anxiety are also related to prolonged fast ${ }^{(10,16,22)}$. On the other hand, it has been consistently demonstrated that CHO-enriched drinks empty the stomach in around one hour and are safe ${ }^{(22,23)}$. In agreement various societies of anesthesiologists have modified their guidelines and are now recommending the intake of clear liquids or CHO-based drinks up to 2 hours before an anesthetic procedure ${ }^{(20)}$.

Glutamine (GLN) is the most abundant amino acid in the human organism, and may improve insulin sensitivity and reduce lean body mass. GLN is considered an essential amino acid during stress and critical illness, and also the main substrate for enterocytes, hepatocytes, lymphocytes, and macrophages ${ }^{(3)}$. Glutamine supplementation may enhance the recovery of surgical patients ${ }^{(4)}$. In normal circumstances, GLN is considered a non-essential amino acid. There is a significant reduction in the serum concentration of glutamine after trauma ${ }^{(3)}$, and healing seems to be accelerated with perioperative glutamine supplementation ${ }^{(6)}$. GLN may also decrease nitrogenous losses, the rate of infectious postoperative complications, and the length of stay $^{(27)}$. GLN may mitigate insulin resistance and consequently reduce hyperglycemia ${ }^{(14)}$.

Declared conflict of interest of all authors: none

Departamento de Cirurgia, Faculdade de Medicina, Universidade Federal de Mato Grosso, Cuiabá, MT, Brasil; ${ }^{2}$ Instituto de Diagnósticos em Medicina - IMEDI, Hospital ${ }^{1}$ Departamento de Cirurgia, Fac
Santa Rosa, Cuiabá, MT, Brasil.

Correspondence: Luigi Rodrigues Brianez. Gastroclínica. Rua Marechal Deodoro, 582, Centro, 78100-005, Cuiabá, MT, Brasil. E-mail: luigibrianez@hotmail.com 
However, only a few studies have assessed the safety of beverages containing GLN to be used as preoperative treatment $2 \mathrm{~h}$ before an operation ${ }^{(7,18)}$. This scarce information urges for new data on the status of gastric residual volume (GRV) after the ingestion of CHO-based drink plus GLN. Thus, the aim of this study was to assess the GRV in healthy young volunteers after the intake of a beverage containing $\mathrm{CHO}$ and GLN.

\section{METHODS}

This was a prospective randomized double blind crossover clinical trial, carried out at the Várzea Grande Magnetic Resonance Institute (Várzea Grande, Brazil), during the period from March to June 2012. The Research Ethics Committee at the Júlio Müller University Hospital approved the study design (protocol No. 998/2011) which is in accordance with the ethics principals set out by the Declaration of Helsinki (2000). The volunteers were invited to participate in this research and signed an Informed Consent Form.

We included 11 male young volunteers (aged between 21 and 30 years-old) with body mass index (BMI) between 20 and $35 \mathrm{~kg} / \mathrm{m}^{2}$ and without either acute or chronic illness in the last 3 months. The criteria for exclusion were non-adherence to any phase of the study protocol, gastroesophageal reflux disease, previous history of intolerance to lactose, gastroparesis or history of poor gastric emptying, diabetes mellitus, and previous abdominal surgery.

\section{Procedures}

Each volunteer was randomized for participation in the study in a blind fashion. All subjects underwent two different protocols before magnetic ressonance (MRI) with an interval of seven days between them. Both phases took place after an overnight fast of eight hours. The volunteers ingested $400 \mathrm{~mL}$ (4 hours before the exam was carried out) at 8:00am and $200 \mathrm{~mL}$ ( 2 hours before the exam was carried out) at 10:00am of a beverage containing either water plus $12.5 \%$ maltodextrin (Phloraceae, Cuiabá, Brazil; $\mathrm{CHO}$ group) or the same beverage plus $15 \mathrm{~g}$ of GLN (Phloraceae, Cuiabá, Brazil; GLN group). The participants were instructed not to ingest alcohol, medication, and caffeine within 24 hours of the study, nor do any vigorous physical activity during that time.

In both phases the individuals were blind to the specific drink and they were told to ingest the beverage in a maximum period of 5 minutes and T0 was defined as the moment they complete the intake of the solution.

The powdered products (maltodextrin alone and maltodextrine plus glutamine) were packed in coded opaque sachets and the content was only known by the pharmacist who manipulates it. The sachets were diluted with water immediately before the ingestion. The radiologist in charge for the MRI analysis was also blind for the study design and phases. The results were decoded only after the end of the experiment. The characteristics and composition of the solutions ingested by the participants can be seen in Table 1 .
TABLE 1. Composition of the solutions

\begin{tabular}{lcccc}
\hline & $\begin{array}{c}\text { CHO } \\
\text { Group } \\
200 \mathrm{~mL}\end{array}$ & $\begin{array}{c}\text { CHO } \\
\text { Group } \\
400 \mathrm{~mL}\end{array}$ & $\begin{array}{c}\text { GLN } \\
\text { Group } \\
200 \mathrm{~mL}\end{array}$ & $\begin{array}{c}\text { GLN } \\
\text { Group }\end{array}$ \\
\hline Energy (Kcal) & 100 & 200 & 160 & 260 \\
Maltodextrin $(\mathrm{g})$ & 25 & 50 & 25 & 50 \\
Glutamine $(\mathrm{g})$ & 0 & 0 & 15 & 15 \\
$\mathrm{Ph}$ & 4.8 & 4.8 & 5.2 & 5.2 \\
Density $(\mathrm{g} / \mathrm{mL})$ & 1.023 & 1.012 & 1.043 & 1.036 \\
Osmolarity $(\mathrm{mOsm} / \mathrm{L})$ & 232 & 232 & 315 & 315 \\
\hline CHO: carbohydrate; GLN: glutamine & & &
\end{tabular}

All the participants in the study underwent magnetic resonance of the upper abdomen at 12:00am and 01:00pm. The GRV observed during the first exam was defined as T120 and the second exam as T180. All exams were performed by the same magnetic resonance equipment (Intera 1.5T; Philips Healthcare, Eindhoven, Holland). Each volunteer was placed in supine position, with a (SENSE) body coil to capture the signal. Transversal acquisitions with 40 cuts (perpendicular in relation to the body's longitudinal axle) were performed in rapid sequences in balanced turbo field-echo (BTFE) with width of cuts of $4.0 \mathrm{~mm}$ at intervals of $3.0 \mathrm{~mm}$. This BTFE (TR [repetition time] $3.64 \mathrm{~ms}$, TE [echo time] $1.82 \mathrm{~ms}$ ) sequence visualizes the liquids with hyper signal, opposing the low signal of the adjacent organs. Each acquisition of a set of images was acquired during an 18 seconds of apnea. Two sequences of exams were carried out for each individual, in the two phases: the first one being 120 minutes after the intake of the solution (T120) and the second, after 180 minutes (T180). The data obtained were analyzed in a work station (Extended Brilliance Workspace; Philips Medical Systems, Holland). GRV was assessed by tracking around the region of interest (ROI) in each cut, forming a volume via the sum of all the ROIs.

Statistical package for social sciences (SPSS) for Windows 11.0 was used for the analyses. The GRV was compared using repeated measures Anova. Categorical data was compared by Fischer test. For statistical comparisons we estimate in all cases the GRV at T0 equals to $200 \mathrm{~mL}$. A $5 \%(P<0.05)$ level was established for statistical significance.

\section{RESULTS}

The clinical characteristics of the volunteers can be seen in Table 2. All participants completed both phases of the

TABLE 2. Characteristics of the volunteers

\begin{tabular}{lc}
\hline Variable & Mean \pm standard deviation (range) \\
\hline Age (years) & $25.5 \pm 3.1(21-30)$ \\
Weight $(\mathrm{Kg})$ & $83.6 \pm 10.5(70-103)$ \\
Height $(\mathrm{m})$ & $1.79 \pm 0.08(1.70-1.90)$ \\
BMI* $\left(\mathrm{Kg} / \mathrm{m}^{2}\right)$ & $26.0 \pm 2.8(21.7-32.5)$ \\
\hline
\end{tabular}

*BMI: body mass index 
study and there were no episodes of nausea or vomiting after intake of the beverage. There were no complications during the course of the MRI which was done without sedation in all cases.

\section{Comparison at $\mathbf{1 2 0}$ minutes}

The GRV found at T120 with the two beverages can be seen in Figure 1. At T120 the mean \pm SD of GRV was similar in the two groups (CHO group: $22.9 \pm 16.6 \mathrm{~mL}$ and GLN group: $19.7 \pm 10.7 \mathrm{~mL} ; P>0.05)$. Gastric emptying as shown in Figure 2 was $88.6 \pm 8.3 \%$ completed in the $\mathrm{CHO}$ group and $90.1 \pm 5.4 \%$ in the GLN group $(P>0.05)$.

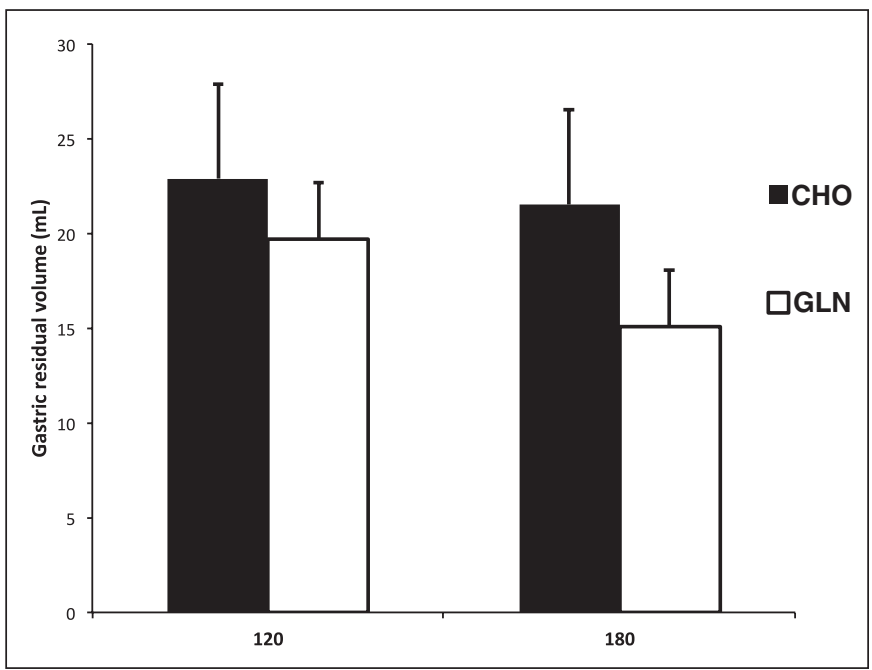

FIGURE 1. Gastric residual volume in the two groups $2 \mathrm{~h}$ (T120) and $3 \mathrm{~h}$ (T180) after the intake of the beverage. Data represent the mean and standard deviation. CHO: beverage with carbohydrate; GLN: beverage with carbohydrate plus glutamine. $P>0.05$ in all the comparisons.

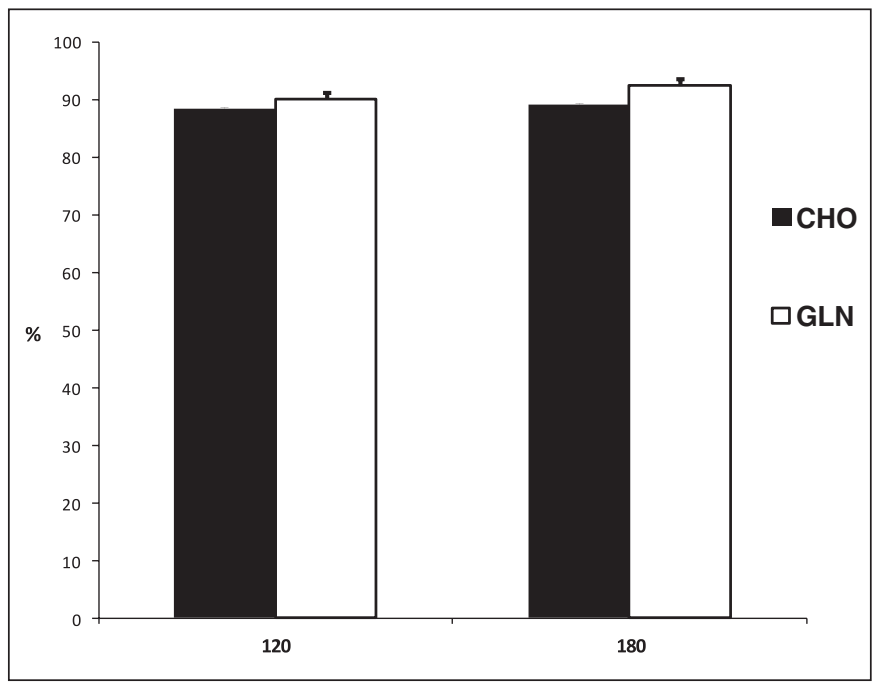

FIGURE 2. Percentages of gastric emptying in the two groups $2 \mathrm{~h}$ (T120) and $3 \mathrm{~h}$ (T180) after the intake of the beverage. Data represent the average. CHO: bevarage with carbohydrate; GLN: beverage with carbohydrate plus glutamine. $P>0.05$ in all comparisons.

\section{Comparison at $\mathbf{1 8 0}$ minutes}

At T180, $89.2 \pm 12.0 \%$ of the beverage in the $\mathrm{CHO}$ group and $92.5 \pm 5.0 \%$ in the GLN group had been evacuated from the gastric chamber (Figure 2). The GRV measured by MRI (Figure 1) was similar with the two formulas (CHO group: $21.5 \pm 24.1 \mathrm{~mL}$ and GLN group: $15.1 \pm 10.1 \mathrm{~mL} ; P>0.05$ ).

At T0 the volume ingested was $200 \mathrm{~mL}$. At T120 and T180 there was emptying of around $90 \%$ of gastric residue $(P<0.05)$ in both groups (Figure 3A and 3B). There was no significant difference $(P>0.05)$ between the two time points (within group comparison) in the two groups.

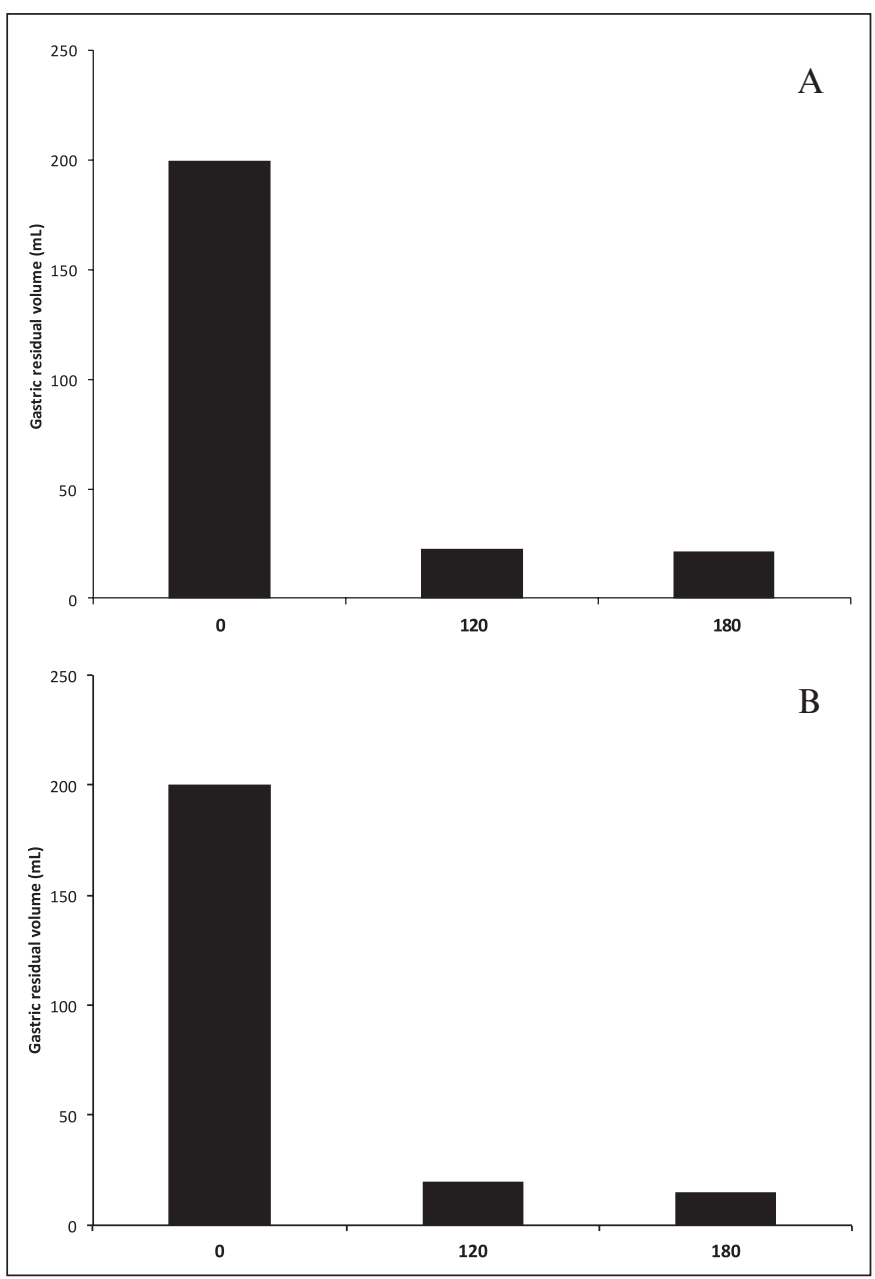

FIGURE 3. Gastric residual volume after carbohydrate drink (A) and after glutamine drink (B). Data represent the mean. T0: time immediately after intake of the beverage (estimated value); T120 $=120$ minutes after the intake of the beverage; T180 = 180 minutes after intake of the beverage. $* P<0.05 \mathrm{~T} 0$ vs T120 and T180.

\section{DISCUSSION}

The overall results haves show that the goals of this study were attained. The findings showed that gastric emptying was satisfactory 2 and 3 hours after the intake of both drinks. This is particularly important because it implies in safety 
for the addition of GLN in CHO-enriched drinks $2 \mathrm{~h}$ before anesthesia.

MRI was a good weapon and perfectly applicable for this type of study. In fact, MRI seems to be one of the most efficient methods described for the assessment of gastric emptying. Several studies have report the efficacy of this exam to assess gastric volume in real time ${ }^{(9)}$. In addition, MRI is a non-invasive exam and avoid collateral effects from radia$\operatorname{tion}^{(9,18)}$. Other methods such as aspiration of the volume via nasogastric tube ${ }^{(7)}$, ultrasonography ${ }^{(24)}$, videofluoroscopy ${ }^{(12)}$, and scintigraphy ${ }^{(13)}$ are also considered less precise than MRI. Gastroscopy is a reliable method to assess gastric emptying but is invasive and may require sedation ${ }^{(25)}$. MRI is an excellent but an expensive tool for the study of gastric emptying. Thus, we are not recommending the use of such a method in clinical basis.

The use of beverages containing carbohydrates has already been recommended by several anesthesiology societies around the world ${ }^{(20)}$. Our findings add new data to increase evidence of safety for the use of hydrolyzed proteins or glutamine in the formulation of these preoperative drinks. The addition of nitrogenous nutrients can increase the benefits of beverage containing only carbohydrates and still modulate the immune response. Other possible benefits of the preoperative use of proteins would be to enhance the control of insulin resistance, improve function and muscle strength in the postoperative period as well as reduce the loss of lean body mass ${ }^{(4,27)}$.

Safety gastric emptying 2-3h after the intake of GLNenriched drinks have been recently reported by Lobo et al. and by Dock-Nascimento et al. Lobo and his colleagues using MRI reported a good gastric emptying after a beverage containing $50 \mathrm{~g}$ carbohydrate and $15 \mathrm{~g}$ GLN 3 hours after being ingested by human volunteers ${ }^{(18)}$. Dock-Nascimento et al., in a randomized controlled study, in video-laparoscopic cholecystectomy reported similar GRV during the induction of anesthesia in groups receiving traditional fast or $2 \mathrm{~h}$ pretreatment with either water, $\mathrm{CHO}$ or $\mathrm{CHO}$ plus $50 \mathrm{~g} \mathrm{GLN}^{(7)}$.

The two drinks tested differed in their osmolarity. However, the higher osmolarity of the beverage used in GLN group did not influenced the gastric emptying in our study. This was probably found because the difference in osmolarity of the two drinks was not expressive. In addition, osmolarity of $\mathrm{CHO}$ drinks did not affected gastric emptying in a human study. The authors concluded that gastric emptying of $\mathrm{CHO}$-enriched solutions is triggered by the $\mathrm{CHO}$-energy drink content ${ }^{(8)}$.

However, the findings in our study deserve some criticism. Firstly, the volunteers were young and healthy and not candidates for any either clinical or surgical treatment. In addition the sample was very small and limited to 11 individuals. Thus, extrapolation of these findings for clinical application should be done with caution. However, crossover studies are adequate and valid in current literature to reply to this type of questioning proposed. Controlled randomized crossover type studies are very important in medical studies. This design enables the subjects to be compared with themselves guaranteeing adequate control groups. This significantly reduces biases and confounding variables of other randomized studies. Finally, we can say that they are statistically efficient, cheap and require few individuals in their design ${ }^{(17)}$. In addition, the use of a tool such as MRI provided trustworthy data for analysis of the results found ${ }^{(9)}$.

Summing up, the results of this study showed that gastric emptying is efficient, and occurs in up to 2 hours after the intake of a beverage containing either $\mathrm{CHO}$ alone or $\mathrm{CHO}$ associated with GLN. Thus, the addition of glutamine to $\mathrm{CHO}$-enriched drink seems to be safe for the use up to $2 \mathrm{~h}$ before an operation. These findings with drinks containing GLN should be furtherly supported by new randomized trials in surgical patients.

Brianez LR, Caporossi C, Moura YW, Dias LA, Leal R, Aguilar Nascimento JE. Volume gástrico residual após ingestão de maltodextrina e glutamina: estudo randomizado, duplo-cego, cruzado. Arq Gastroenterol. 2014,51(2):123-7.

RESUMO - Contexto - A adição de glutamina à bebidas de pré-operatório pode aumentar os benefícios do carboidrato isolado. Objetivo - Avaliar o volume gástrico residual após ingestão de bebida contendo carboidrato mais glutamina. Métodos - Onze voluntários saudáveis (de 24 à 30 anos) foram randomizados em um estudo cruzado para ingerirem $400 \mathrm{~mL}$ ( $4 \mathrm{~h}$ antes) e $200 \mathrm{~mL}$ ( $2 \mathrm{~h}$ antes) de bebida contendo $12,5 \%$ de maltodextrina (grupo carboidrato) ou 12,5\% de maltodextrina mais $15 \mathrm{~g}$ de glutamina (grupo glutamina), em dois momentos distintos, com intervalo de 7 dias entres eles. A ressonância magnética foi realizada para medir o volume gástrico residual (mL) 120 e 180 minutos após a última ingestão. Resultados - Foi encontrado um volume gástrico residual semelhante à condição basal de jejum após $2 \mathrm{~h}$ e $3 \mathrm{~h}$ da ingestão das bebidas. Não houve diferença na média \pm DP do volume gástrico residual $(\mathrm{mL})$ encontrada aos 120 minutos (grupo carboidrato: $22.9 \pm 16.6$ e grupo glutamina: $19.7 \pm 10.7 ; P>0.05$ ) e aos 180 minutos (grupo carboidrato: $21.5 \pm 24.1$ e grupo glutamina: $15.1 \pm 10.1 ; P>0.05$ ) entre as duas bebidas. Conclusão - O esvaziamento gástrico é eficiente e ocorre em até $2 \mathrm{~h}$ apos a ingesta de bebida contendo apenas carboidrato ou carboidrato associado à glutamina. Assim, a adição de glutamina à bebidas enriquecidas com carboidrato parece ser segura para uso até $2 \mathrm{~h}$ antes da operação.

DESCRITORES - Esvaziamento gástrico. Cuidados pré-operatórios. Carboidratos. Glutamina. Imagem por ressonância magnética. 


\section{REFERENCES}

1. Aguilar-Nascimento JE, Bicudo-Salomão A, Caporossi C, Silva RM, Cardoso EA, Santos TP. Enhancing surgical recovery in Central-West Brazil: The ACERTO protocol results. e-SPEN, The European e-Journal of Clinical Nutrition and Metabolism. 2008;3:e78-e83.

2. Aguilar-Nascimento JE, Perrone F, de Assunção Prado LI. Preoperative fasting of 8 hours or 2 hours: what does evidence reveal? Rev Col Bras Cir. 2009;36:350-2.

3. Al Balushi RM, Cohen J, Banks M, Paratz JD. The clinical role of glutamine supplementation in patients with multiple trauma: a narrative review. Anaesth Intensive Care. 2013;41:24-34.

4. Awad S, Lobo DN. What's new in perioperative nutritional support? Curr Opin Anaesthesiol. 2011;24:339-48

5. Bicudo-Salomão A, Meireles MB, Caporossi C, Crotti PL, de Aguilar-Nascimento JE. Impact of the ACERTO project in the postoperative morbi-mortality in a university hospital. Rev Col Bras Cir. 2011;38:3-10.

6. Blass SC, Goost H, Tolba RH, Stoffel-Wagner B, Kabir K, Burger C, et al. Time to wound closure in trauma patients with disorders in wound healing is shortened by supplements containing antioxidant micronutrients and glutamine: a PRCT. ClinNutr. 2012;31:469-75.

7. Borges Dock-Nascimento D, Aguilar-Nascimento JE, Caporossi C, Sepulveda Magalhães Faria M, Bragagnolo R, Caporossi FS, et al. Safety of oral glutamine in the abbreviation of preoperative fasting; a double-blind, controlled, randomized clinical trial. NutrHosp. 2011;26:86-90.

8. Brouns F, Senden J, Beckers EJ, Saris WH. Osmolarity does not affect the gastric emptying rate of oral rehydration solutions. JPEN J Parenter Enteral Nutr. 1995; 19:403-6.

9. Carbone SF, Tanganelli I, Capodivento S, Ricci V, Volterrani L. Magnetic resonance imaging in the evaluation of the gastric emptying and antral motion: Feasibility and reproducibility of a fast not invasive technique. Eur J Radiol. 2010;75:212-4

10. Faria MS, de Aguilar-Nascimento JE, Pimenta OS, Alvarenga LC Jr, Dock-Nascimento DB, et al. Preoperative fasting of 2 hours minimize insulin resistance and organic response to trauma after video-cholecystectomy: a randomized, controlled, clinical trial. World J Surg. 2009;33:1158-64.

11. Fearon KC, Ljungqvist O, Von Meyenfeldt M, Revhaug A, Dejong CH, Lassen $\mathrm{K}$, et al. Enhanced recovery after surgery: a consensus review of clinical care for patients undergoing colonic resection. ClinNutr. 2005;24:466-77.

12. Firman CM, Costa MM, Costa ML, Lemme E. Qualitative and quantitative evaluation of gastric emptying using a videofluoroscopic method. Arq Gastroenterol. 2000;37:81-8.
13. Gentilcore D, Hausken T, Horowitz M, Jones KL. Measurements of gastric emptying of low-and-high-nutrient liquids using 3D-ultrasonography and scintigraphy in healthy subjects. Neurogastroenterol Motil. 2006;18:1062-8.

14. Grau T, Bonet A, Miñambres E, Piñeiro L, Irles JA, Robles A, et al. The effect of 1-alanyl-1-glutamine dipeptide supplemented total parenteral nutrition on infection morbidity and insulin sensitivity in critically ill patients. Crit Care Med 2011;39:1263-8.

15. Gustafsson UO, Ljungqvist $O$. Perioperative nutritional management in digestive tract surgery. Curr Opin Clin Nutr Metab Care. 2011;14:504-9.

16. Hausel J, Nygren J, Thorell A, Lagerkranser M, Ljungqvist O. Randomized clinical trial of the effects of oral preoperative carbohydrates on postoperative nausea and vomiting after laparoscopic cholecystectomy. Br J Surg. 2005;92:415-21.

17. Jones B; Kenward MG. Design and analysis of cross-over trials. $3^{\text {rd }}$ ed. London: Chapman and Hall. 2012.

18. Lobo DN, Hendry PO, Rodrigues G, Marciani L, Totman JJ, Wright JW, et al. Gastric emptying of three liquid oral preoperative metabolic preconditioning regimens measured by magnetic resonance imaging in healthy adult volunteers: A randomized double-blind, crossover study. Clin Nutr. 2009;28:636-41.

19. Maltby JR. Fasting from midnight - the history behind the dogma. Best Pract Res Clin Anaesthesiol. 2006;20:363-78.

20. Malty JR. Preoperative fasting guidelines. Can J Surg. 2006;49:138-9.

21. Mendelson CL. The aspiration of stomach contents into the lungs during obstetric anesthesia. Am J Obstet Gynecol. 1946;52:191-205.

22. NygrenJ, Thorell A, Jacobsson H, Larsson S, Schnell PO, Hylén L, et al. Preoperative gastric emptying. Effects of anxiety and oral carbohydrate administration. Ann Surg. 1995;222:728-34.

23. Nygren J. The metabolic effects of fasting and surgery. Best Pract Res Clin Anaesthesiol. 2006;20:429-38.

24. Perlas A, Chan VW, Lupu CM, Mitsakakis N, Hanbidge A. Ultrasound assessment of gastric content and volume. Anesthesiology. 2009;111:82-9.

25. Perlas A, Mitsakakis N, Liu L, Cino M, Haldipur N, Davis L, et al. Validation of a mathematical model for ultrasound assessment of gastric volume by gastroscopic examination. Anesth Analg. 2013;116:357-63.

26. Varadhan KK, Lobo DN, Ljungqvist O. Enhanced recovery after surgery: the future of improving surgical care. Crit Care Clin. 2010;26:527-47.

27. Weitzel LR, Wischmeyer PE. Glutamine in critical illness: the time has come, the time is now. Crit Care Clin. 2010;26:515-25.

28. Zheng Y, Li F, Qi B, Luo B, Sun H, Liu S, et al. Application of perioperative immunonutrition for gastrointestinal surgery: a meta-analysis of randomized controlled trials. Asia Pac J Clin Nutr. 2007;16:253-7. 